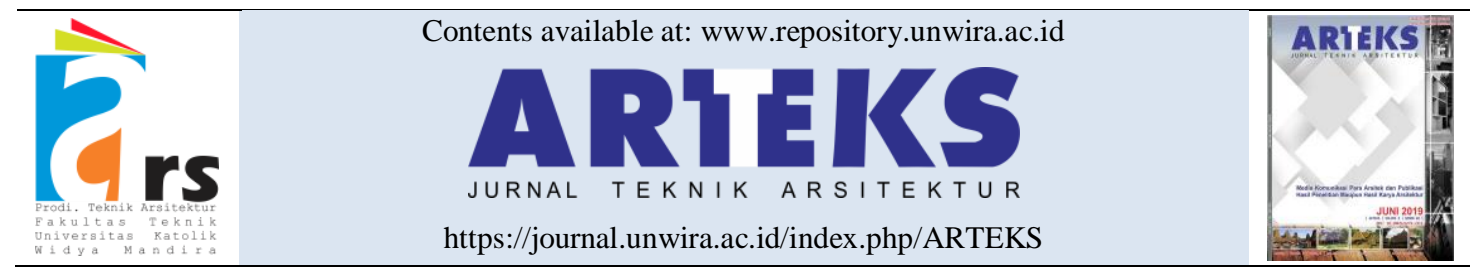

Research paper

doi: $10.30822 /$ arteks.v5i3.488

\title{
The use of minimal surface principles and multiplex joinery system for designing post-disaster construction systems
}

\section{Stephanus Evert Indrawan*id, Gervasius Herry Purwoko ${ }^{\circledR}$, Tri Noviyanto P. Utomo}

Department of Architecture, Faculty of Creative Industries, Universitas Ciputra CitraLand CBD Boulevard, Made, Surabaya, Indonesia

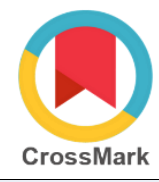

\begin{tabular}{l}
\hline ARTICLE INFO \\
\hline Article history: \\
Received May 05, 2020 \\
Received in revised form May 14, 2020 \\
Accepted July 26, 2020 \\
Available online December 01, 2020
\end{tabular}

Keywords:

Disaster-prone

Joinery system

Minimal surface

Multiplex construction system

Pneumatic structure

*Corresponding author: Stephanus Evert Indrawan

Department of Architecture, Faculty of Creative Industries, Universitas Ciputra, Indonesia

Email: sindrawan@ciputra.ac.id

ORCID: https://orcid.org/0000-0001-74532999

\section{ABSTRACT}

Indonesia is located in a geographic area that is prone to disasters; thus, it is necessary to raise awareness about the science of disaster mitigation, including the provision of safe/suitable temporary shelter/building facilities for victims. In a number of disasters, it can be seen that confusion and access to the affected transportation will lead to difficulties in delivering disaster relief and supporting equipment to build post-disaster facilities. Therefore, we need a construction system that is easily assembled, stable, and easy to carry. In this case, the designer uses one type of shell structure, i.e. Minimum Surface principle which is the basis of the Inflatable Structure or Pneumatic Structure. By developing lightweight structures that refer to this principle, the designer can process architectural forms that are lighter and more stable. In this paper, the discussion is limited to the use of materials made from plywood based on the principle of Minimal Surface structure because this material is easily obtained and processed. The research questions of this study are how to create a fast raft construction system for postdisaster needs with plywood base material and how to process the connection system or plywood construction to have structural capability.

\section{Introduction}

Due to its geographical location, Indonesia is prone to disasters (Ulum 2013). Therefore, it is necessary to raise awareness about disaster mitigation including the provision of safe/suitable temporary shelter/building facilities for disaster victims.

Disasters that occurred in several places have damaged the environment and transportation infrastructure, making the level of difficulty even worse, especially in sending food aid and equipment to provide temporary shelter buildings (Wibowo, Surbakti, and Yunus 2013). Therefore, it needs building that is safe, stable, easily dismantled, and comfortable enough (Makdori 2019).

A type of building that meets those criteria is a shell structure building, i.e. a building that has a curved, rigid, and thin surface so that it remains stable but is economically more efficient (Karamoy and Suryono 2016). The shell structure is a combination of curve intersections from the horizontal and vertical directions or an inverse comparison of the tent structures. This building structure is very stable though it has a drawback, i.e. the designer is very dependent on the fabricator in the process of development. 
On the other hand, the design process of the shell structure is quite complex consisting of many stages depending on the physical model that must be made first. Therefore, if something goes wrong and needs some revisions or adjustments, all of the steps need to be done from the scratch which requires an expensive investment and takes times. If the building implementing the minimal surface principle is used as a temporary postdisaster shelter, this raises problems on what method to design the structural system that is considered to be in accordance with the characteristics and the level of damage caused by disasters that generally occur in Indonesia, what fabrication systems and assembly in the field, and the level of stability and security.

This research is an experimental model with a parametric approach and computational design method in the design and fabrication process where the utilization of digital knowledge makes it easy to complete the back and forth process in the design stage. The results of this study present the building models that can be used to create earthquake resistant non-permanent structures for post-disaster facilities.

Indonesia is located in the ring of fire and the meeting point between continental plates which make it very vulnerable to disasters (Madona and Irmansyah 2013). Therefore, it is necessary to raise awareness about disaster mitigation including the provision of safe/suitable temporary shelter/building facilities for disaster victims (Karima, Firzal, and Faisal 2020). Based on experience that occurred during the Aceh and Yogyakarta earthquake, it took days to reach the disaster site using conventional vehicles and equipment due to the badly damage of environment and transportation infrastructure, especially in sending food aid and equipment to provide temporary shelter buildings. With continuous earthquakes and aftershocks, the criteria for a safe, stable, easily dismantled and installed, and quite comfortable building are major considerations (Wikantiyoso 2010). A type of building that meets those criteria is a shell structure building, i.e. a building that has a curved, rigid, and thin surface so that it remains stable but is economically more efficient and easily movable. The shell structure is a combination of curve intersections from the horizontal and vertical directions or an inverse comparison of the tent structures.

The structure of this building is very stable but the designer is very dependent on the fabricator in the process of development (Nugrahini 2020). On the other hand, the design process of the shell structure is quite complex consisting of many stages depending on the physical model that must be made first. Therefore, if something goes wrong and needs some revisions or adjustments, all of the steps need to be done from the scratch which requires an expensive investment and takes times.

With the advantages of the building with the minimal surface principles and supported by digital fabrication technology, this construction system is considered to be very potential as a post temporary shelter model that has a high level of accessibility difficulties. Therefore, the research problems proposed in this study are: (1) What type of construction joinery can be applied to assemble buildings that are considered in accordance with the characteristics and level of damage caused by disasters commonly occur in Indonesia? (2) How is the system design and assembly method in the field?

\section{Result and discussion}

The modern world demands the productivity of the building designer including the effectiveness and efficiency in working with all the support of modern production methods. This has divided the two domains in the practice of Architecture, namely design and construction. Product design aims to present ideas and concepts into image formations, while products from construction bring images into work in the field. Therefore, it is unclear that there is a bridge connecting the design and construction process as a whole (Gonzalez et al. 2020). In more specific and complex conditions such as active surface structure, one of them is a shell structure. In the process of designing a shell structure, there is a process of aesthetic interaction, structure knowledge, and mathematics. Intense collaboration is also needed to create a good design, stable structure, and even the ability to realize it, called a fabricator.

\section{Digital fabrication}

Digital fabrication is a digital design activity which involves fabrication machines controlled through a computer, e.g. a $3 \mathrm{~d}$ printer, computer numeric controller, etc. Digital Fabrication is also known as Rapid Prototyping Labs. In the late 90s, laboratories using digital fabrication were found 
in progressive architecture schools. Of course, there is a historical background that explains this change. In 1923 and 1928, László Moholy-Nagy, a Hungarian professor from Bauhaus, offered a concept in education i.e. the quality of material which is influenced by industrial processes. Lecturers and students worked together to find methods of processing materials through an experimental process. After World War 2, this process developed more rapidly while at the same time engineering and science began to be integrated in architectural education. In 1960, the concepts of operative design, artificial intelligence and computing technology began to emerge (Celani 2012). The objectives are:

1. Better design through better processes;

2. Involves disciplines outside Architecture;

3. Utilization of computers to do repetitive work.

\section{Digital tectonics and digital design}

Digital tectonics and digital design of computational technology are related to the understanding of digital design which in its development can bring the design process closer to fabrication. Sheila Kennedy divides design practice into two categories. First, horizontal design needs conventional stages of design and requires sufficient knowledge in each stage. Second, vertical design utilizes various design approaches from various fields of science and it is more experimental and involves technology intensively. In tectonics, a modeling object is likened to a virtual and physical material. Here are some digital tectonic approaches that are currently unwittingly used by architects today (Oxman 2012):

1. As a virtual material tool, where digital design is able to clearly communicate the material's texture. Better known as 3D rendering.

2. As a physical material that is able to simulate the deformation of an object design to the conditions that affect it, such as gravity, wind and load.

3. As a structural material which is able to increase economic value and efficiency. As a tool to explore the formations.

4. As a tool to accommodate the adaptive ability of materials that are affected by the performance of the material system.

\section{Shell structure}

Shell structure is more widely applied to buildings that have wide spans, for example in Sydney opera house, Jakarta MPR Building, Montreal Biosphere Canada, etc.

Based on the forming forces, it is a structure that has a membrane-like formation where the principle of structural forces is reversed. Membrane structure and tent structure are formed due to tensile force, while shell structures are formed due to compressive forces (Adriaenssens 2014).

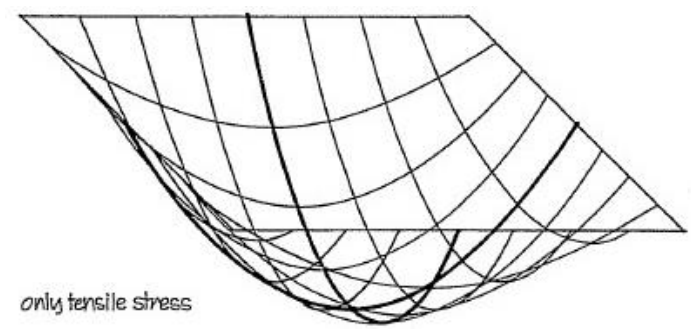

Figure 1. Principles of tent structure

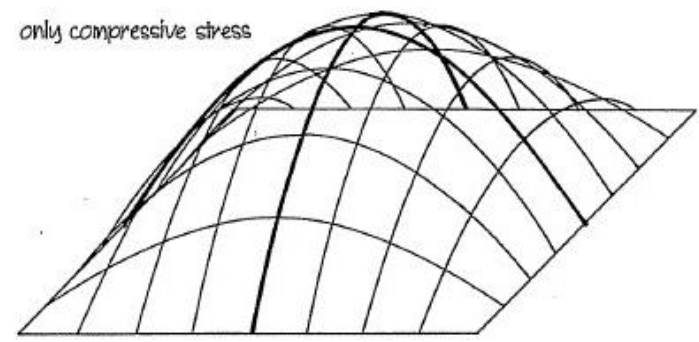

Figure 2. Principles of shell structure

Based on the forming curve, shell structure can be divided into 2, namely: Cylinder shells shaped like tunnels. This structure has a longitudinal span and the curvature is perpendicular to the cross-section diameter. In general, the forming materials of this structure consists of a series of rigid materials such as composite concrete or steel.

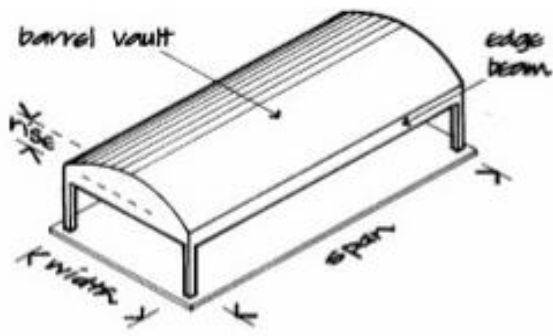

Long Span Barret Vauit

Figure 3. Long barrel shell Source: (Padrawala 2018) 
The ball-shaped dome shell. This structure has a two-way longitudinal span or can also be considered a revolving curve on the axis of the object. In general, the forming materials of this structure consists of a series of rigid structural materials such as composite concrete or steel. However, the advantages of this structure can be made from a series of rigid line elements and repetitive arrangement of patterns such as geodesic domes. Furthermore, this two-way curve series is referred to as a Mesh or grid series that forms boxes on the surface of the shell (Engel 2007). This mesh concept allows the surface to be formed flexibly and logically from the construction process side.

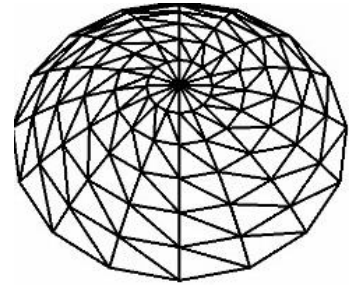

(c) Schwedler dome

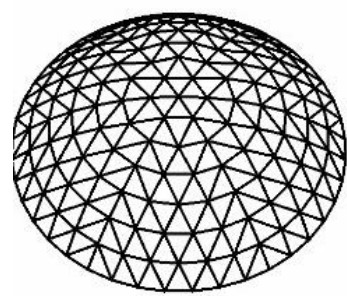

(g) Diamatic dome

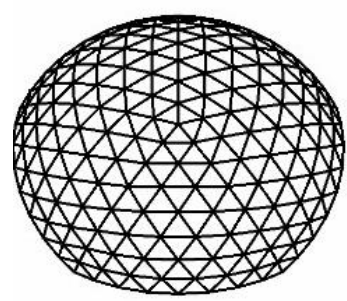

(k) Geodesic dome

Figure 4. Dome shell type Source: (Sciffo, n.d.)
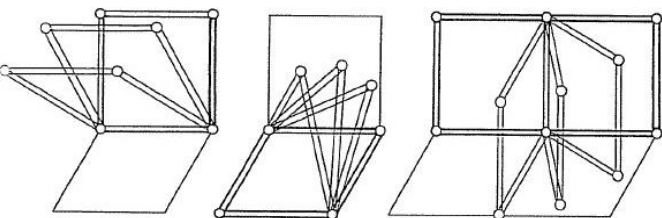

Fornsteverung durch Maschenwinkel, Form manipulation through mesh angle Figure 5. Mesh unit module
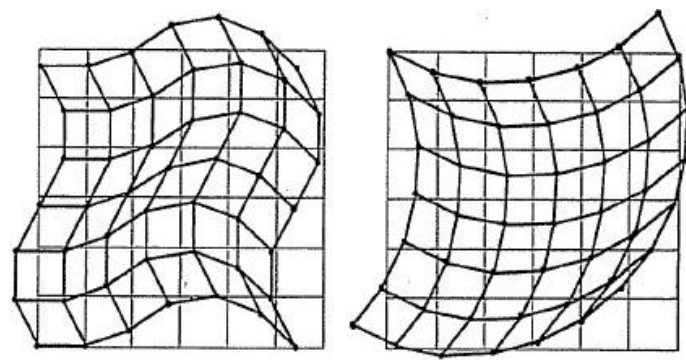

Flexibility of the uniform mesh pattern in the plane lattice Figure 6. A series of flexible mesh

\section{Formation exploration process}

The use of physical models for the exploration process has been carried out since the Renaissance by Gaudi by making use of a chain of hangings. At that time, Gaudi was able to show the results of an aesthetic physical model but there was no supporting explanation for how the force was transferred through the chain. Until now, the surface form plays an important role in the design of the shell structure. The designer is highly dependent on 3-dimensional formation and simulation of the ability to press and pull plays an important role. During the history of architecture, a lot of calculation methods and physical models were developed by Architects, Civil Engineers, and Fabricators or Contractors to produce optimal and efficient shell structures. In the pre-computer age, the form-follow-force principle was commonly used to find out and simulate mechanical engineering principle models using flexible membrane materials such as latex cloth. Exploration methods through physical models are divided into 3 categories based on fabrication requirements (Adriaenssens 2014):

Hanging model

Based on the formation structure principle, modeling object is formed due to the gravitational force in the forming material. Therefore, it can be assumed that the material experiences a tensile strength due to gravity and experiences a compressive force when the object is turned upwards. Architect Heinz Isler explored the formation through this method (figure 8) and Frei Otto used an iron chain to find grid patterns and mesh applications on the surface of the shell as seen in figure 7.

Tension model

This method uses soap bubbles (figure 9) and flexible latex or bandages to find a stable surface based on predetermined curves. This method also strongly represents the formation of tent structures. Frei Otto used this method to approach 
the design of the Stuttgart train station project. The purpose of this method is to reach a minimum surface (figure 10).

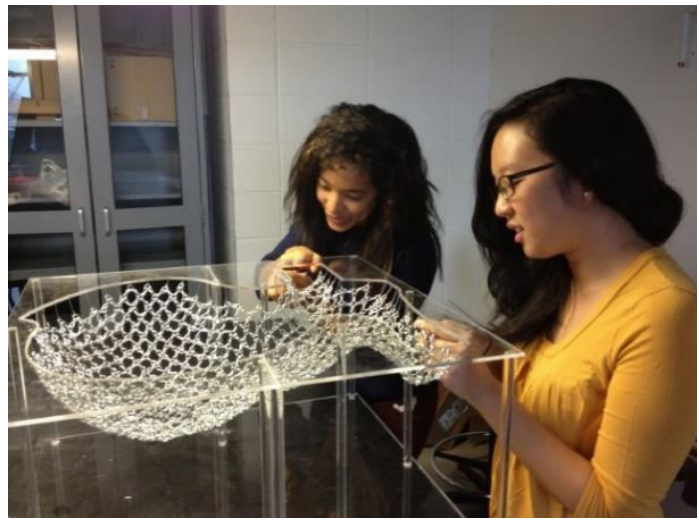

Figure 7. Hanging model

Source: (Department of Civil and Environmental Engineering - Princeton University 2013)

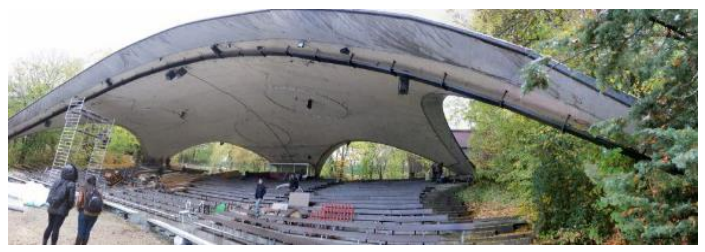

Figure 8. Naturtheater Groetzingen

Source: (Maurer, O'Grady, and Tung 2013)

Pneumatic model

Pneumatic model is an inflatable structural model using a bubble mixture or a sheet of fabriclike material that is able to hold air. The work process is to blow the material until it reaches certain limits and objectives of the designer. The pneumatic structure is adapted as the most efficient form concept for the structure of the shell and the principle of this structure is also utilized to process the mold of the structural material.

Therefore, it can be seen that the physical model approach is an attempt by designers to achieve the principle of form-follow-force. However, this effort is only to fulfill the rules and structural logic. The selected model needs to be processed into a series of work drawings that have size, scale, and technical proportions as architectural drawings that can be delivered to related parties of the project, such as civil engineers, contractors, and fabricator of architectural elements.

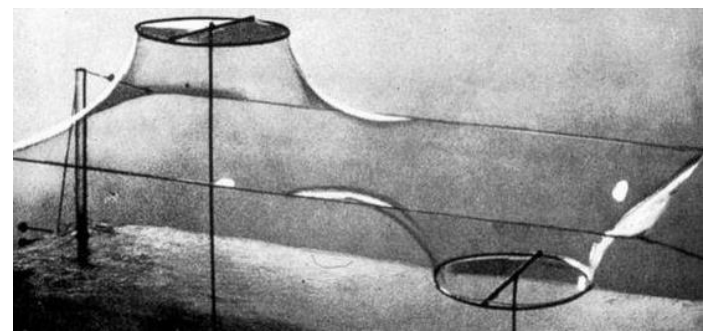

Figure 9. Soap bubbles mockups Source: (Zexin and Mei 2017)

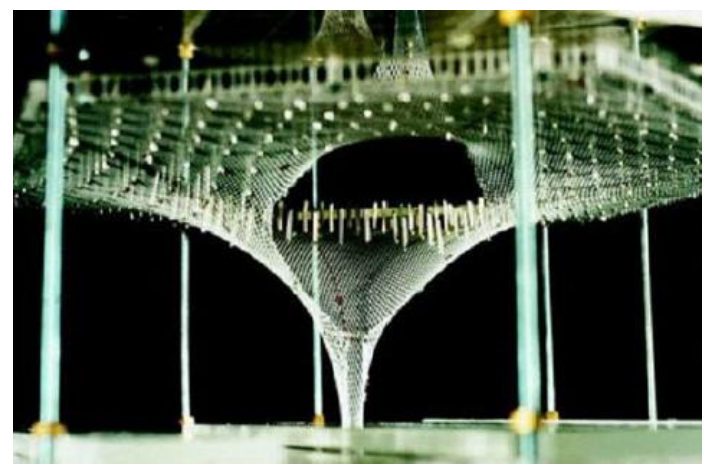

Figure 10. Mockup of the Stuttgart Train Station Source: (Callanta 2020)

Since 1960, computational techniques and various structural analysis methods have become very important in realizing the structure of the shell.

\section{Software and design process}

Therefore, it can be concluded that digital design is a combination of mechanical and architectural technical knowledge. Metal fabrication capabilities for a car can be a solution for creating complex and repetitive architectural components. Software is a vital supporting tool in realizing this concept. However, CAD-based software has not been able to solve the complexity of existing geometry. So far, the use of CAD software can only operate in Cartesian coordinates (xyz) and cannot accommodate operations on curved and organic surfaces. UV mapping can be the answer in solving this problem. The UV operating system can be likened to a patchwork where the designer can process each part flexibly. So far, CAD serves as a tool that functions to move hand drawings into digital data conducted by a draftsman or CAD operator. There is no design activity that interacts directly with the data as a whole. Designer expectations require a computer to be used as a design investigation tool. The following explains the flow of conventional and digital design schemes: 


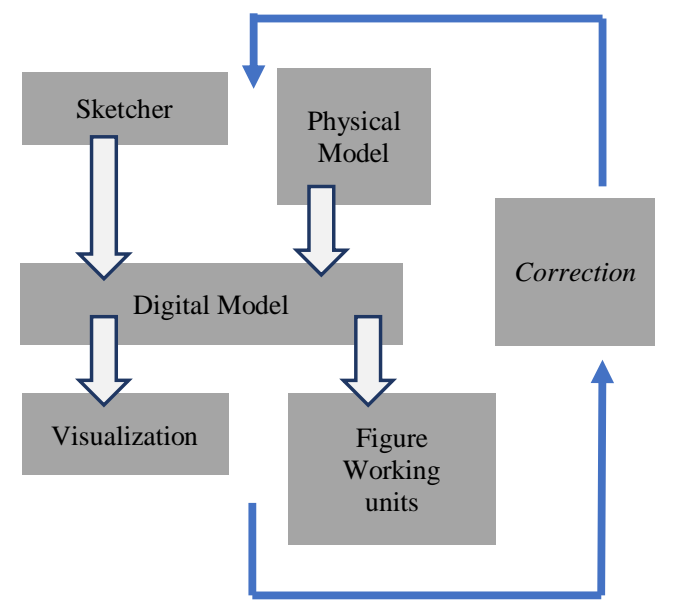

Scheme 1. CAD flow

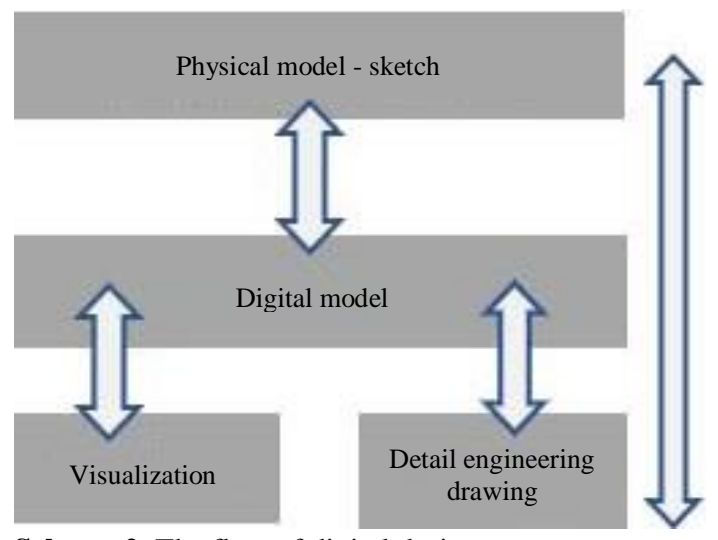

Scheme 2. The flow of digital design

\section{Design method}

The design method used is controlled experimental/semi structured experiments. The purpose of this experiment is to achieve the formation of a plastic shell structure. This experimental object was conducted by third-year students of Interior and Architecture at Ciputra University. The control of this experiment is to ensure that students recognize shell structure theory in general and digitally think and design processes. On the one hand, students understand the theory and history of construction but need specific guidance to combine it with digital design.

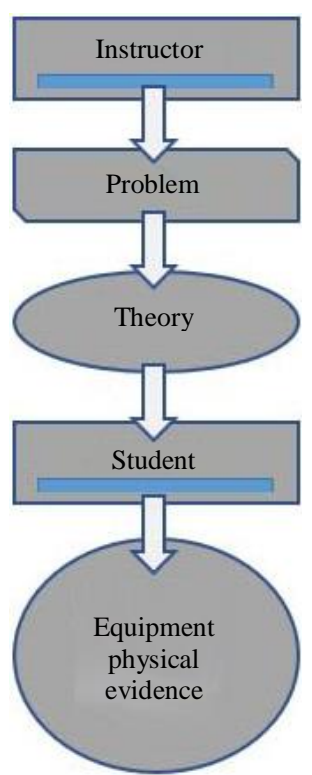

Scheme 2. Semi structured experiment

\section{Tessellation and slices}

It is similar with orthogonal projections used to recognize the formation of design objects and proceed to the process of realization or construction (assembly). The contractor and related engineer are expected to be able to understand the architectural components through a series of detailed images that are processed through the orthogonal projection method. Therefore, the authors consider there is a method to break down the formation components of the shell structure that is difficult to communicate if only through orthogonal projection.

The shell structure needs to be decomposed in the process of design through fragments. Afterwards, these fragments are put back together into a whole object and can be built at various scales. Therefore, the authors chose the approach of digital fabrication methods. Digital fabrication methods consist of 5 main categories namely sectioning, tessellating, folding, contouring, and forming (Iwamoto 2009). Tessellating method was chosen in this study; thus, this paper does not discuss exploration of design through other methods.

Tessellation is a collection of fragments that are arranged in line with one another in order to form a surface. This method can create 3dimensional objects when using sufficient information (dimensions or assembly methods). This method is known through the geometrical drawings by MC Escher in which these formations are often likened as fragments or 
mesh. Tessellation can also be considered a mosaic during the Byzantine empire in Rome or the stained-glass window in the Gothic church window. These examples serve an understanding of design that begins with an artist's understanding of small pieces which are then processed into an object.

Digital design gives designers the possibility to make varied modulations through non-standard fabrication procedures. Therefore, the tessellation method can create curved surfaces and other organic forms through digital approaches through planar material. There are 2 main methods for treating organic surfaces digitally: NURBS (Non-Uniform Rational BSplines) approach, i.e. through flexible curve formations and curved surfaces; and Mesh modellers using polygons and subdivision arranged to achieve desired smooth surface. Polygonal Mesh is usually composed of triangles and rectangles.

This study used Geodesic Dome by Buckminster Fuller as a case study. The purpose of geodesic design is to achieve a structure that is lightweight and efficient from a technical standpoint where this design is also prepared for mass production and is universal. The dome itself was built from an identical arrangement of triangles and hexagonal shapes, apparently at the time of structural realization the building was very stable and not deformed.

Furthermore, this method is combined with the slice method. This method is not intended to make the surface of an object, but to connect each panel by turning each panel in a different direction so that each edge is perpendicular to each other. By using Rhinoceros software, the intervals between sections can be easily set. The series of parts is also an element or structure that forms the surface of the element.

\section{Material-digital fabrication}

Plywood is the main material for this experiment because it commonly uses for construction purposes.

Table 1. Material-digital fabrication

\begin{tabular}{|c|c|c|}
\hline Product lifecycle & Definition & Application \\
\hline Raw material extraction & $\begin{array}{l}\text { The DfE Principle impacts the process of extracting } \\
\text { raw materials, including material selection, material } \\
\text { identification, and the process of extracting raw } \\
\text { materials from the environment }\end{array}$ & $\begin{array}{l}\text { Plywood material is a local material } \\
\text { with various qualities to meet various } \\
\text { needs }\end{array}$ \\
\hline Material processing & $\begin{array}{l}\text { The DfE principle impacts the processes that turn raw } \\
\text { materials into finished materials and products }\end{array}$ & $\begin{array}{l}\text { Sectioning and diagrid methods allow } \\
\text { the design to rely on joint design and } \\
\text { reduce the use of binder }\end{array}$ \\
\hline $\begin{array}{l}\text { Component } \\
\text { manufacturing }\end{array}$ & $\begin{array}{l}\text { The DfE principle impacts the manufacture of the } \\
\text { individual components of a product }\end{array}$ & $\begin{array}{l}\text { Digital fabrication can overcome the } \\
\text { limitations of material module }\end{array}$ \\
\hline Assembly & $\begin{array}{l}\text { The DfE principle impacts the final assembly of both } \\
\text { individual components produced on-site and } \\
\text { components manufactured by suppliers }\end{array}$ & $\begin{array}{l}\text { Assembling process becomes faster, } \\
\text { thereby reducing energy use }\end{array}$ \\
\hline Packaging & $\begin{array}{l}\text { The DeF principle impacts life cycle considerations } \\
\text { of a product's packaging }\end{array}$ & $\begin{array}{l}\text { Flatpack method can reduce the } \\
\text { volume of goodssignificantly }\end{array}$ \\
\hline $\begin{array}{l}\text { Transportation and } \\
\text { distribution }\end{array}$ & $\begin{array}{l}\text { The DeF principle impacts the transportation and } \\
\text { distribution of goods, from final assembly to the } \\
\text { customer }\end{array}$ & $\begin{array}{l}\text { Product of digital precision is more } \\
\text { precise, allowing the users make ease } \\
\text { of the assembling process }\end{array}$ \\
\hline Installation and use & $\begin{array}{l}\text { The DfE principle impacts the use phase of a } \\
\text { product's life cycle, specifically product's } \\
\text { interactions with the user }\end{array}$ & Depending on the materials used \\
\hline $\begin{array}{l}\text { Uppgrading and } \\
\text { maintance }\end{array}$ & $\begin{array}{l}\text { The DfE principle impacts services that address the } \\
\text { shortcomings of a product experienced during use }\end{array}$ & $\begin{array}{l}\text { This section method is structural in } \\
\text { nature, so other complementary } \\
\text { elements can be added to it }\end{array}$ \\
\hline Staying alive & $\begin{array}{l}\text { The DfE principle impacts all product lifecycle } \\
\text { phases, with the goal increasing the amount of time it } \\
\text { spends in the use phase, delaying the end of life of a } \\
\text { product }\end{array}$ & $\begin{array}{l}\text { This section method is structural in } \\
\text { nature, so other complementary } \\
\text { elements can be added to it }\end{array}$ \\
\hline End of life & $\begin{array}{l}\text { The DfE principle impacts what happens to a product } \\
\text { after it can no longer be made use of in its current } \\
\text { condition; includes recycling and biodegradability }\end{array}$ & $\begin{array}{l}\text { The neatness working result of } \mathrm{CNC} \\
\text { machine allows to use materials in any } \\
\text { size }\end{array}$ \\
\hline Transmaterialization & $\begin{array}{l}\text { The DfE principle relates to collection of information } \\
\text { throughout the whole life cycle of the product, and } \\
\text { open communication of the information }\end{array}$ & $\begin{array}{l}\text { Designers are directly involced in the } \\
\text { process }\end{array}$ \\
\hline
\end{tabular}




\begin{tabular}{lll}
\hline Product lifecycle & Definition & Application \\
\hline Pervasive & $\begin{array}{l}\text { The DfE principle applies to all phases of the product } \\
\text { lifecycle }\end{array}$ & $\begin{array}{l}\text { Digital technology makes it possible to } \\
\text { make the design becomes more } \\
\text { specific and allows the designer to } \\
\text { identify material from a different angle }\end{array}$ \\
\hline Business practices & $\begin{array}{l}\text { The DfE principle concerns business practices; it is } \\
\text { independent of the product's lifecycle or production }\end{array}$ & $\begin{array}{l}\text { Progress of green technology can } \\
\text { support the production of digital } \\
\text { design }\end{array}$ \\
\hline
\end{tabular}

The sectioning, tessellation method, and material process through $\mathrm{CNC}$ machine and computer help the designer resolves the limitations of size (one sheet of plywood (the average size of one Plywood sheet is $1.20 \mathrm{x}$ 2.40m). Table contents show the assessment results by using the rubric of DfE (Indrawan 2017). Plywood, as the main construction material, has a different potential through the digital fabrications approach. Digital Fabrication gives a possibility to Digital Fabrication Laboratory has become part of the study design; therefore, interdisciplinary knowledge from other disciplines is now required.

Digital fabrication, as well as orthographic projection, is a tool to communicate ideas (Indrawan 2017). Though the method of material processing through digital fabrication requires the designers to have more involvement in the process, the working process is more simplified. In the making process of this pavilion, all participants involved in the project are students and instructors without any professional construction workers. Digital fabrication also allows the designer to realize complex formation with the contemporary premise.

The implementation of the shell structure principles through a combination of the tessrelation and slince methods on the minimal surface

Shell structure occurs because the compressive force is inversely proportional to the tent structure that uses tensile force. The shell structure type used is single barrel vault. In this experiment, the surface formed is a series of semicircular curves, where the semicircular series is assumed to be the same as the Hooke curve (in reverse condition). The structural mechanism that occurs is shown in the figure, where (a) is the compressive force of the arc, (b) horizontal reaction, and (c) vertical reaction.

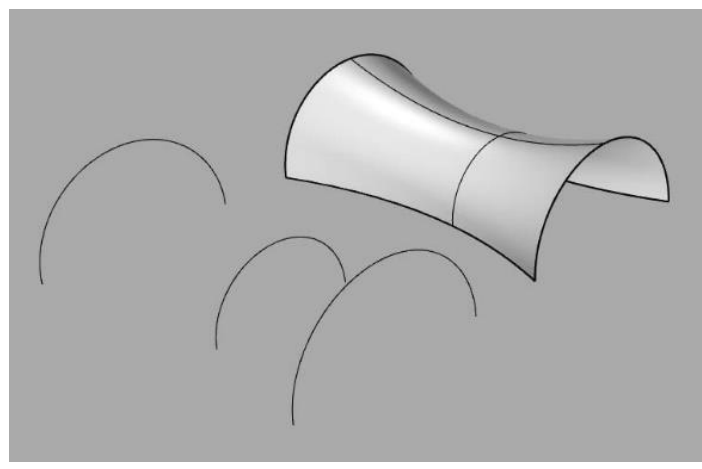

Figure 11. Curve and loft

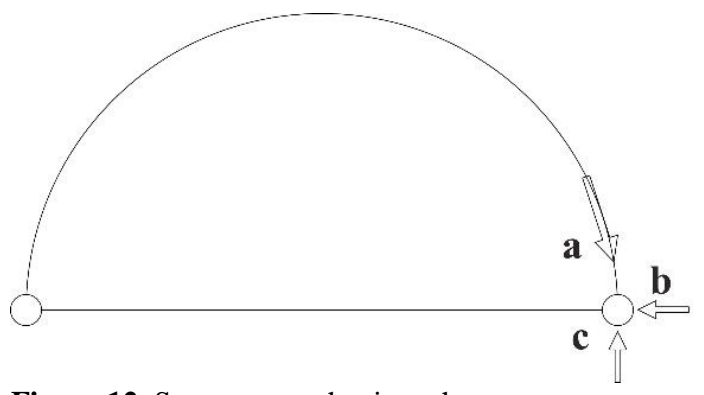

Figure 12. Structure mechanics scheme

This study focuses on the use of plywood material. Plywood is used because it is easy to find and the quality of the material can be adjusted to the needs of users such as engineered wood. Since plywood formations tend to be planar, a greater amount of material is needed in order to form a wide span. Therefore, surface formations need to be divided into equilateral triangle-shaped segments, with the aim that each triangular component forms a scoping space that has structural capabilities. This method is called tessellation because it arranges patterns lined up with each other like mosaics. Figure (a) is front view, while Figure (b) is top view. Meanwhile, Number 1, 2, and 3 are the order in which the fields are formed up to their division. In every creation of objects in a computer program, each geometry element has specific coordinates and numbering systems. 


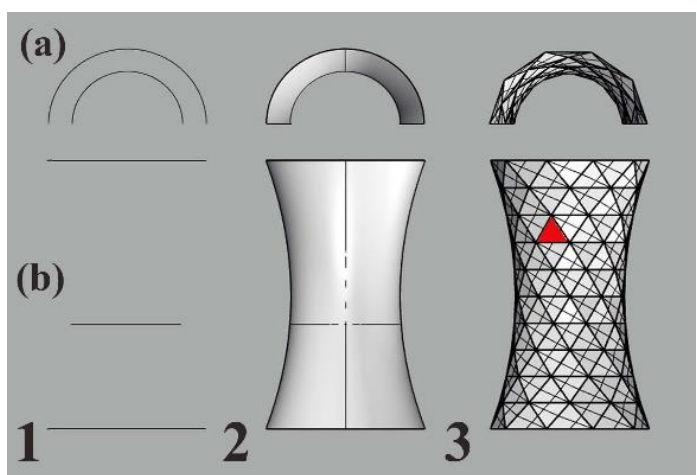

Figure 13. The order of panel design is curves, loft, and triangulation panel

This step is called surface typology adjustment or Boundary Representation. The colors and numbers explain that the order of each component has been arranged in order.

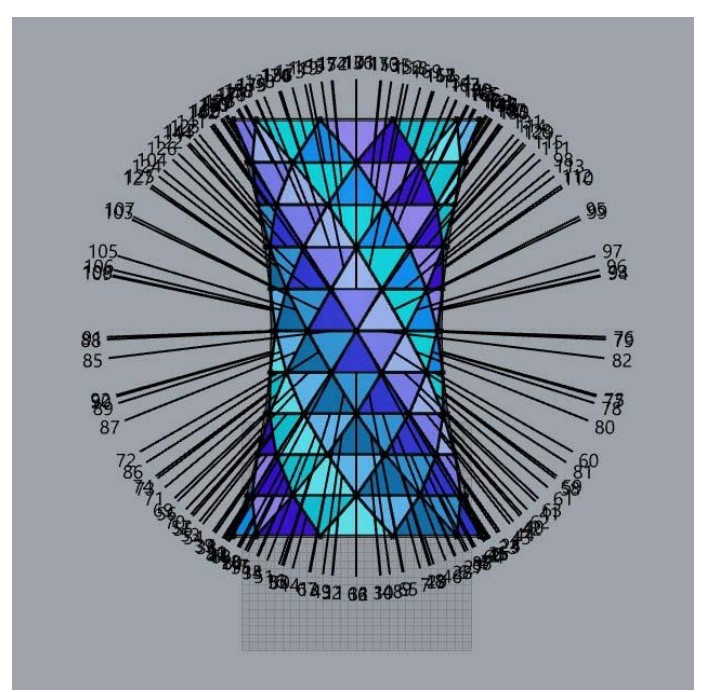

Figure 14. Brep topology

Furthermore, each component is spaced according to needs or according to the thickness of the material so that it is flexible in following the expected shape (a). On each side of the isosceles triangle, notch is made to place the connecting elements between materials where the components intersect with the equilateral triangle component (b). The figure shows the surface with material thickness (c).

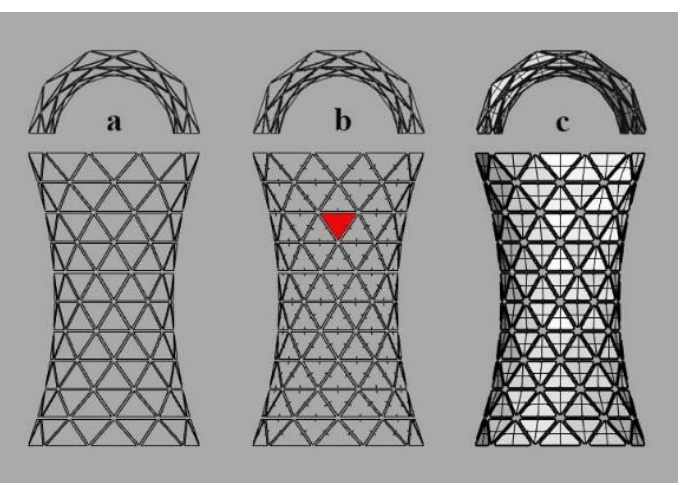

Figure 15. The order of tessellation and slice component design

Components that function as connectors have a shape and intersect. Thus, there will be pressure on each other components.

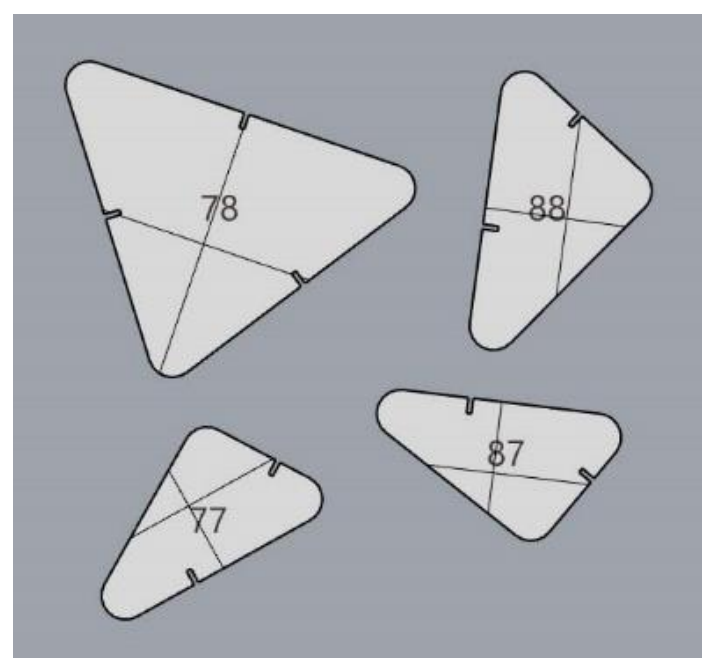

Figure 16. Tessellation component with numbers

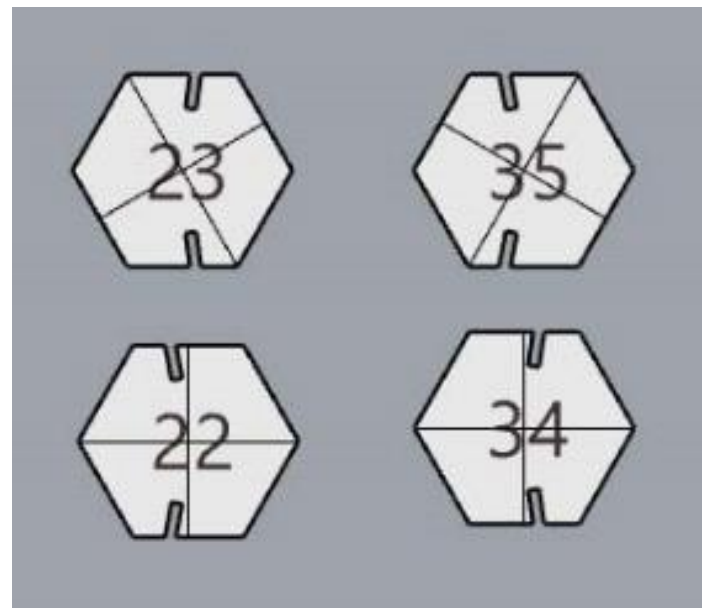

Figure 17. Component of slices with numbers 
In each component of the tessellation and slices, structural mechanics can be seen, where (a) exerting compressive forces, (b) horizontal reactions, (c) providing vertical reactions, (d) constituting the dead load of a whole series of structures. The figure shows the arrangement of components that can form a scope. Each component is arranged by utilizing the frictional strength of the texture of the plywood, so that it does not need glue or other joints.

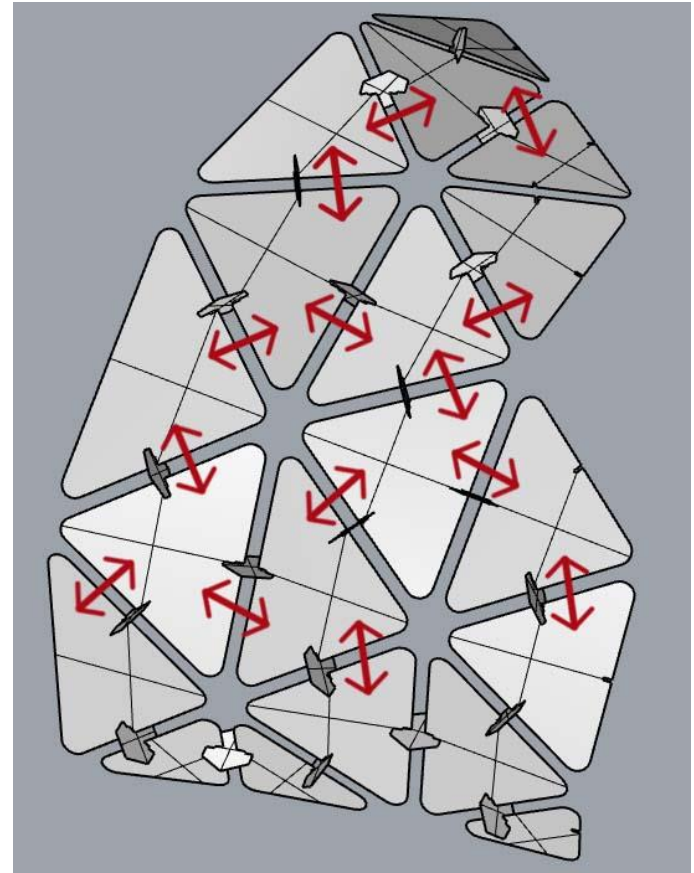

Figure 18. Each component gives compressive force to one another

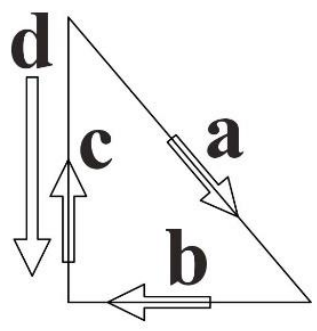

Figure 19. Structure mechanics scheme

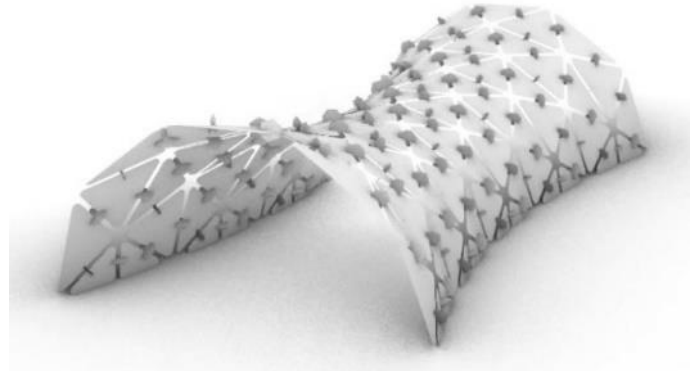

Figure 20. 3D modeling

Because each of these components has dimensions that are not too large, they can be used as disaster mitigation facilities in remote areas. All of these designs are arranged in a series of algorithms using grasshopper software:

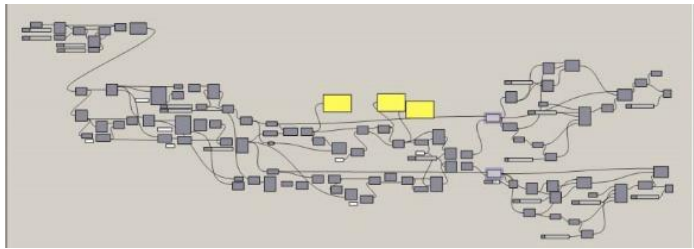

Figure 21. Algorithm in grasshopper application

Table 2. The parameters of this design are:

\begin{tabular}{llll}
\hline No. & Parameters & Size & Unit \\
\hline 1 & Arc diameter & 3500 & $\mathrm{~mm}$ \\
\hline 2 & $\begin{array}{l}\text { Distance between } \\
\text { arcs }\end{array}$ & 2500 & $\mathrm{~mm}$ \\
\hline 3 & $\begin{array}{l}\text { Surface (triangle) } \\
\text { division }\end{array}$ & $50 \times 100$ & $\mathrm{U} \mathrm{x} \mathrm{V}$ \\
\hline 4 & $\begin{array}{l}\text { Offset (distance) } \\
\text { between panel } \\
\text { surfaces }\end{array}$ & 18 & $\mathrm{~mm}$ \\
\hline 5 & Slot depth & 20 & $\mathrm{~mm}$ \\
\hline
\end{tabular}

Each of these parameters can be set through slider or numbers entered into a series of algorithms. Therefore, it can be changed without repeating the design process from the beginning.

\section{Conclusion}

From the aforementioned explanation, it can be concluded that the understanding of the past structure can be reviewed through an understanding of digital channels. The flow of digital design allows Architects to create architectural works that are more economical, functional, and appropriate. The experiments conducted aimed to create a scope for disaster 
mitigation facilities that are lightweight, easy to transport, flexible and parametric materials. Each size and formation of these architectural objects can be changed in accordance with the parameters in the algorithm formula; thus, users will not be trapped in rigid structural modules. Nowadays, plywood material has a wide variety of quality and production. Plywood is possible to have structural capabilities and are produced in an environmentally friendly manner.

\section{References}

Adriaenssens, Sigrid. 2014. Shell Structures for Architecture. $\quad$ Routledge. https://doi.org/10.4324/9781315849270.

Callanta, Julian. 2020. 'Urban Architecture: Suspend Model for Form Finding of the Arches for the New Train Station in Stuttgart, Germany, 2000 (Christoph Ingenhoven and Partner, Frei Otto, Büro Happold, Leonhardt and Andrae)'. 2020. https://www.pinterest.com/pin/31701126124 3639594/.

Celani, Gabriela. 2012. 'Digital Fabrication Laboratories: Pedagogy and Impacts on Architectural Education'. Nexus Network Journal $14 \quad$ (3): 469-82. https://doi.org/10.1007/s00004-012-0120-x.

Department of Civil and Environmental Engineering - Princeton University. 2013. 'A Social and Multi-Dimensional Exploration of Structures'. Evolution of German Shells Efficiency in Form. 2013. http://shells.princeton.edu/course.html.

Engel, Heino. 2007. Structure Systems. 3rd ed. Berlin, Germany: Hatje Cantz Verlag.

Gonzalez, Arturo, Michael Schorr, Benjamin Valdez, and Alejandro Mungaray. 2020. 'Bridges: Structures and Materials, Ancient and Modern'. In Infrastructure Management and Construction. IntechOpen. https://doi.org/10.5772/intechopen.90718.

Indrawan, Stephanus Evert. 2017. 'Design for Environment and Form Findings through Digital Fabrication'. DIMENSI (Journal of Architecture and Built Environment) 44 (2). https://doi.org/10.9744/dimensi.44.2.171178.

Iwamoto, Lisa. 2009. Digital Fabrications: Architectural and Material Techniques
(Architecture Briefs). Hudson, New York: Princeton Architectural Press.

Karamoy, Megawati, and Suryono. 2016. 'Eksplorasi Struktur Cangkang Untuk Bangunan Tinggi'. MEDIA MATRASAIN 13 (1). https://ejournal.unsrat.ac.id/index.php/jmm/ar ticle/view/14520.

Karima, Miftahul, Yohannes Firzal, and Gun Faisal. 2020. 'Penerapan Prinsip Desain Arsitektur Biofilik Pada Riau Mitigation and Disaster Management Center'. ARTEKS: Jurnal Teknik Arsitektur 5 (2): 307-16. https://doi.org/10.30822/arteks.v5i2.448.

Madona, Era, and Muhammad Irmansyah. 2013. 'Aplikasi Metode Nearest Neighbor Pada Penentuan Jalur Evakuasi Terpendek Untuk Daerah Rawan Gempa Dan Tsunami'. Elektro: Jurnal Ilimah 5 (2): 39-46. https://doi.org/https://doi.org/10.30630/eji.5.2 .52 .

Makdori, Yopi. 2019. 'BNPB: Mitigasi Bencana Masyarakat Indonesia Masih Di Bawah Standar'. Liputan6, 18 February 2019. https://www.liputan6.com/news/read/390632 5/bnpb-mitigasi-bencana-masyarakatindonesia-masih-di-bawah-standar.

Maurer, Tessa, Elizabeth O'Grady, and Ellen Tung. 2013. 'Hanging Membrane: The Naturtheater Grotzingen'. Evolution of German Shells Efficiency in Form. 2013. http://shells.princeton.edu/Grotz.html.

Nugrahini, Fibria Conytin. 2020. 'Struktur Cangkang Bentukan Bebas Dengan Material Non-Beton Bertulang: Penunjang Arsitektur Organik'. Agregat 5 (1). http://journal.umsurabaya.ac.id/index.php/Agregat/article/vie w/4982.

Oxman, Rivka. 2012. 'Informed Tectonics in Material-Based Design'. Design Studies 33 (5): 427-55. https://doi.org/10.1016/j.destud.2012.05.005.

Padrawala, Taha. 2018. 'Shell Structure'. Slide Share. 2018. https://www.slideshare.net/TAHA0786/shellstructure-95305431.

Sciffo, Roberto. n.d. 'Dome Shell Types - Natural Spaces Domes'. Pinterest. https://www.pinterest.com/pin/30927069941 0083523/.

Ulum, Mochamad Chazienul. 2013. 'Governance Dan Capacity Building Dalam Manajemen Bencana Banjir Di Indonesia'. Jurnal Dialog Penanggulangan Bencana 4 (2): 5-12. 
https://bnpb.go.id/uploads/migration/pubs/59 5.pdf.

Wibowo, Agus, Indra Surbakti, and Ridwan Yunus. 2013. 'Indonesia Disaster Database'. Sendai, Japan. https://www.unescap.org/sites/default/files/S 2-3_Indonesia.pdf.

Wikantiyoso, Respati. 2010. 'Mitigasi Bencana Di Perkotaan; Adaptasi Atau Antisipasi Perencanaan Dan Perancangan Kota? (Potensi Kearifan Lokal Dalam Perencanaan Dan Perancangan Kota Untuk Upaya Mitigasi
Bencana)'. Local Wisdom: Jurnal Ilmiah Kajian Kearifan Lokal 2 (1). http://jurnal.unmer.ac.id/index.php/lw/article/ view/1368.

Zexin, Sun, and Hongyuan Mei. 2017. 'Robotic Form-Finding and Construction Based on the Architectural Projection Logic'. IOP Conference Series: Materials Science and Engineering $216 \quad$ (June): 012058. https://doi.org/10.1088/1757899X/216/1/012058. 